\title{
Efficiency on the Slovak Private Pension Funds Markets and Legislative Changes Effects Analysis ${ }^{1}$
}

\author{
Veronika MITKOVA - Vladimír MLYNAROVIC̈*
}

\begin{abstract}
The paper presents applications of portfolio techniques including proposed modification of the Black-Litterman approach for pension funds' performance evaluation on the Slovak private pension funds markets and deals with: how effective are the investment strategies of companies on the market of specific pension funds; if the investment strategies outcomes match the companies' officially declared fund strategy type in a risk-return space; and if the legislative changes on the pension market segment impact those funds strategies. Relative positions of single funds are identified by constructing efficient frontiers in various spaces. As a result, the investment strategies create clusters for conservative, balanced, and index funds, while the growth funds have higher strategies variance. It is shown that the legislative changes concerning mainly more risky funds have an important influence on the second pillar growth funds investment strategies. The results show high interactions between legislative changes and investment decisions.
\end{abstract}

Keywords: Black-Litterman approach, private pension funds, investment strategies JEL Classification: G11

DOI: https://doi.org/10.31577/ekoncas.2021.06.03

\section{Introduction}

The paper focuses on the efficient frontiers' construction in two different risk-return spaces and exhibits the outcomes of the portfolio managers' decisions under various government regulations. The dataset captures the whole officially

\footnotetext{
* Veronika MITKOVA, corresponding author - Vladimír MLYNAROVIČ, Comenius University in Bratislava, Faculty of Social and Economic Sciences, Institute of Economics, Mlynské luhy 4, 82105 Bratislava, Slovakia; e-mail: veronika.mitkova@fses.uniba.sk; vladimir. mlynarovic@ fses.uniba.sk

${ }^{1}$ This paper research was supported by the Slovak Research and Development Agency, project No. APVV-17-0551 Balancing Out the Imbalances: Redefining the View on Macroeconomic Imbalances under the European Governance Framework and by the Slovak Ministry of Education, Science and Sport by grant VEGA No. 1/0628/20: The Relationship between International Investment Position and Economic Growth - Potential Indicator of Country's External Imbalances.
} 
disposable data timespan of the existence of the Slovak private pension system market, hence the analysis based on the data and a unique methodology presented in this paper provides a complex evaluation of the investment strategies in various funds and environments. The paper presents a complex analysis of the Slovak private pension funds market and provides answers to three fundamental questions.

1. The first part of the research focuses on the efficiency of the private Slovak pension funds market on which the second and third pillars are analyzed together. How effective is the company strategy of its single pension fund in various environments? There are generated efficient frontiers for risk-return measures and the position of each fund is analyzed.

2. Do the companies' investment strategies outcomes match the declared types of four strategies - conservative, balanced, growth, and indexed?

3. How do the legislative changes impact the company's pension investment funds strategies? Is there a change in the efficient frontier dependent on the legislative changes?

Historical overview of the pension system in Slovakia: In the past, Slovakia ran only an unfunded pay-as-you-go mandatory pension system based on Bismarck's Germany model of the 19th century, in which average life expectancy did not substantially exceed the retirement age. The demographic crisis and high rate of unemployment caused, that the system was not able to finance promises it gave to former contributors and raised a need for reform. Three pillar pension system was created in January 2005. The first pillar is the previous, but reformed pay-as-you-go mandatory un-funded system run by the state; second fully funded pillar based on the principle of savings, mandatory/voluntary in time, run by private pension companies (hereinafter referred to as DSS); and third voluntary pillar consisting of various forms pension and life insurance run by private pension companies (hereinafter referred to as DDS). At the beginning of the pension reform, all citizens in productive age will have to decide whether to begin saving on their pension accounts or stay in the reformed first pillar. Young people first entering the labor market and self-employees were obliged to enter the second pillar. Others, once entering the second pillar there was no way back. Each pension company was obliged to create and manage three pension funds with different portfolio: conservative, balanced, and growth fund with exact investment limits (conservative: $80 \%$ bonds and $20 \%$ stocks, balanced $50 \%$ bonds and $50 \%$ stocks, growth $20 \%$ bonds, and $80 \%$ stocks). For the time being, the regulations for entering or exit the second pillar and pension funds investment strategies changed by legislative regulation.

The structure of this paper is as follows: The second chapter provides a comprehensive literature review, the third deals with the mathematical backgrounds and the methodology developed for the private pension funds efficiency analysis 
in selected periods. The fourth chapter presents the data used and the legislative changes influencing the pension companies' strategies. The fifth chapter contains the results and is divided into two main parts: in the first part the questions 1 and 2 related to pension funds' performance are answered together and in the second part the impacts of the legislative changes are examined. The conclusion part summarizes the findings of the paper.

\section{Literature Review}

The fundamental matter of the second and third pillars' management is based on the portfolio selection problem. There are some well-known approaches to the portfolio selection problem, including the Markowitz (1952) and Black-Literman (BL) (Black and Litterman, 1991) models used in this paper. The Markowitz portfolio selection problem is being extended in many directions. At least two of them are useful for our purposes. The first one is using various risk measures (Konno, Waki and Yukki, 2002), (Rockafellar and Uryasev, 2000) as a reaction to the unattainability of the assumption of the normal distribution asset returns. It is also well known that one of the limitations of the mean-variance approach (Markowitz, 1952) is that its recommended asset allocations are highly sensitive to small changes in inputs and, therefore, to estimation error, mainly in expected returns, see i.e. Michaud (1989), Chopra (1993) and Hurley and Brimberg (2015). The second direction used in this paper, the Black-Literman approach (Black and Litterman, 1991) as an attempt to solve problems connected to possible errors in expected returns estimation, this approach is widely used in pension funds asset allocation, see Da Silva, Lee and Pornrojnangkool (2009), Jones, Lim and Zangari (2007), Cheung (2010). Kolm, Tutuncu and Fabozzi (2014) provides a comprehensive overview of models and trends in portfolio optimization and places the BL model among them. For the empirical evidence of the use of the BL model, see e.g. Bessler, Opfer and Wolff (2017) who prove that BL optimized portfolios outperform naïve-diversified portfolios, mean-variance, Bayes-Stein, and minimumvariance strategies; Platanakis and Sutcliffe (2017) used it for asset-liability modeling and pension schemes on over 144 samples reaching a remarkably stable asset allocation supported by six robustness checks. Oikonomou, Platanakis and Sutcliffe (2018) proves by six different approaches that socially responsible investment portfolios based on „formal“ optimization approaches (including BL) have superior risk-return rates than portfolios based on more simplistic approaches. Martin and Sankaran (2019) on six years dataset of partially correct opinions of small-cap and emerging market stocks show a high correlation of the BL expected returns for large-cap US stocks with their future five-year returns. Jayeola et al. 
$(2017 ; 2018)$ use the BL model to prove that the efficient portfolio cannot be constructed without diversification of assets to riskless (treasury bill) and risky (gold, silver, platinum, oil) assets together and evaluated that investment in gold acts as safe during an economic recession. Jakubik, Melichercik and Sevcovic (2009) discusses the sensitivity of stock proportion in Slovak pension funds' portfolios to the savings level and prove its linearity with respect to the contribution rate.

The Black-Litterman approach was further extended and modified, e.g. by Martellini and Ziemann (2007) who extended it by non-trivial preferences about higher moments of asset return distribution; further Bertsimas, Gupta and Paschalidis (2012) replaced the statistical base of the model with ideas from arbitrage pricing theory and volatility uncertainty; Lejeune (2011) constructs fund-of-funds based on a probabilistic integer, non-convex optimization problem. Kara, Ulucan and Atici (2019) used GARCH modeling to predict indicators for the stocks and transformed them to return forecasts through Support Vector Regression to get investor views vector incorporated into the BL model. Pang and Karan (2018) replaced the multi-variate normal distribution with multi-variate elliptical distributions in the risk measure and derived a closed-form solution in the BL model. Rodrigues and Lleo (2018) combined standard and behavioral portfolio theories; Gnedenko and Yelnik (2016) used a geometric interpretation of quadratic programming: using tracking error as a distance of measure included the optimal unconstrained factor portfolio to all feasible portfolios to get an optimal solution. Jia and Gao (2016) used the inverse optimization technique to extend the BL approach by the variance of the stock, the updated estimation of the expected return and covariance matrix was found by solving a semidefinite programming problem. Vyrost and Lyocsa (2014) used co-exceedance and mean-variance distances between assets instead of usual correlations. Zhou (2009) uses Bayesian learning to exploit all available information as market views, proprietary investor views, and the data.

An extensive review of computable general and partial equilibrium models dealing with a pension, aging, and social security issues is provided by Fehr (2009; 2016) provides the reviews of CGE models dealing with social security. Makarski, Hagemejer and Tyrowicz (2017) compares the welfare effects and fiscal costs of replacing the pay-as-you-go defined benefit system by contribution system and found that funding the pension system gap with public debt allows an intergenerational redistribution. With the intergenerational fairness of pension schemes deals Kryger (2011) in his paper Fairness versus efficiency of pension schemes. Adema, Meijdam and Verbon (2009) explores by a two-country two-period overlapping-generations model benefits and costs of countries with a PAYG and funded pension systems under Pareto efficiency condition in European countries. 
Guardiancich (2011) examined the vision towards a single occupational pension market of European Union's countries proposed by the European Commission's Institutions for Occupational Retirement Provision Directive. Casarico (1998) uses a two-period overlapping generations model with investments in human capital and capital market imperfections to study the effects of a pension reform on lifetime opportunities and output. The same methodology was used in Artus (2000). Bian, Li and Yao (2018) propose an equilibrium investment strategy for a defined-contribution pension plan under various conditions. Kotesovcova (2011) provides the evaluation of pension funds by the investment performance of pension systems in 23 countries. Table 1 summarizes the literature review for the portfolio optimization methodology applied to pension funds efficiency.

Table 1

\section{Literature Review}

\begin{tabular}{|c|c|c|c|}
\hline Authors & Country & Timespan & Method \\
\hline Fehr, 1999 & Germany & Simulation & $\begin{array}{l}\text { Auerbach-Kotlikoff } \\
\text { simulation model }\end{array}$ \\
\hline Kilianova et al., 2006 & Slovakia & Jan 1996 - June 2002 & $N A$ \\
\hline Barros and Garcia, 2007 & Portugal & $1994-2003$ & $\begin{array}{l}\text { Cobb-Douglas stochastic } \\
\text { cost frontier model }\end{array}$ \\
\hline Mitkova et al., 2007 & Slovakia & $2005-2007$ & $\begin{array}{l}\text { Promethee methods, } \\
\text { Black-Litterman approach }\end{array}$ \\
\hline Garcia, 2010 & Portugal & $1994-2007$ & DEA-Malmquist index \\
\hline $\begin{array}{l}\text { Angelidis and } \\
\text { Tessaromatis, } 2010\end{array}$ & Greece & 2005 & $N A$ \\
\hline Gokgoz, 2010 & Turkey & $2006-2007$ & DEA \\
\hline $\begin{array}{l}\text { Marti-Ballester and } \\
\text { Prior-Jimenez, } 2010\end{array}$ & Spain & $N A$ & $\begin{array}{l}\text { DEA, additive frontier } \\
\text { models }\end{array}$ \\
\hline $\begin{array}{l}\text { Serbanescu and Pele, } \\
2011\end{array}$ & Poland & $2002-2009$ & Binary logistic regression \\
\hline López and Walker, 2021 & Italy & $1989-2006$ & Econometric estimation \\
\hline $\begin{array}{l}\text { Gokcen and Yalcin, } \\
2015\end{array}$ & Turkey & $2004-2011$ & Sharpe model \\
\hline Mavlutova et al., 2016 & Latvia & $2009-2015$ & $N A$ \\
\hline $\begin{array}{l}\text { Foo and Witkowska, } \\
2016\end{array}$ & $\begin{array}{l}\text { Poland, Germany, UK, } \\
\text { Europe, USA }\end{array}$ & $2002-2013$ & Sharpe model \\
\hline Uyen, 2016 & $\begin{array}{l}\text { Argentina, Bolivia, } \\
\text { Colombia, Chile, Costa } \\
\text { Rica, Dominican } \\
\text { Republic, Mexico, Peru, } \\
\text { El Salvador, Uruguay }\end{array}$ & $2005-2015$ & DEA method \\
\hline $\begin{array}{l}\text { Kompa and Witkowska, } \\
2016\end{array}$ & Poland & $1999-2013$ & $\begin{array}{l}\text { Sharpe model, } \\
\text { Treynor ratios }\end{array}$ \\
\hline Mlynarovic, 2016 & Slovakia & Apr 2005 - Aug 2015 & Black-Litterman approach \\
\hline Matic and Cobovic, 2017 & Croatia & $N A$ & Comparative analysis \\
\hline Sun, 2017 & China & $N A$ & Partial equilibrium analysis \\
\hline $\begin{array}{l}\text { De la Torre-Torres et al., } \\
2019\end{array}$ & Mexico & Jan 2005 - July 2018 & $\begin{array}{l}\text { Two-regime } \\
\text { Markov-switching analysis }\end{array}$ \\
\hline Witkowska et al., 2019 & Poland & $2009-2015$ & Sharpe model (CAPM) \\
\hline Bottazzi et al., 2011 & Chile & $2003-2017$ & Sharpe model \\
\hline
\end{tabular}

Source: Authors. 


\section{Mathematical Backgrounds}

A decision-able tool for efficiency analysis in a selected segment of financial markets is an efficient frontier of the segment in a selected risk-return space. The Markowitz portfolio selection problem (Markowitz, 1952; 1959) can be generalized as a multiple criteria optimization problem written as:

$$
\text { eff }\left\{f_{1}(\mathbf{w}), f_{2}(\mathbf{w}) \mid \mathbf{w} \in W\right\}
$$

where

$$
W=\left\{\mathbf{w} \in R^{n} \mid \mathbf{e}^{T} \mathbf{w}=1, \mathbf{w} \geq 0, E_{*} \leq f_{1}(\mathbf{w}) \leq E^{*}\right\}
$$

and

$f_{1}(\mathbf{w})$ - a return measure scalar function,

$f_{2}(\mathbf{w})$ - a risk measure scalar function,

w - the vector of portfolio weights,

$n$ - the number of assets on the selected segment,

e - the vector which elements equal 1 ,

while

$$
\begin{gathered}
E_{*}=f_{1}\left(\mathbf{w}_{*}\right) \text { and } E^{*}=f_{1}\left(\mathbf{w}^{*}\right) \\
\mathbf{w}_{*}=\operatorname{argmin}\left\{f_{2}(\mathbf{w}) \mid \mathbf{e}^{T} \mathbf{w}=1, \mathbf{w} \geq 0\right\} \\
\mathbf{w}^{*}=\operatorname{argmax}\left\{f_{1}(\mathbf{w}) \mid \mathbf{e}^{T} \mathbf{w}=1, \mathbf{w} \geq 0\right\}
\end{gathered}
$$

and a constrained method (Steuer, 1989), (Mavrotas, 2009) is used to solve the problem (2.1).

In the analysis of the efficiency on the market of the private Slovak pension funds, it is assumed that

$$
\begin{gathered}
f_{1}(\mathbf{w})=\mathbf{E}^{T} \mathbf{w} \\
f_{2}(\mathbf{w})=C \operatorname{VaR}_{\beta}(\mathbf{w}, \beta)=\frac{1}{1-\beta} E\left[-r(\mathbf{w}) \mid-r(\mathbf{w}) \geq \operatorname{VaR}_{\beta}(\mathbf{w})\right]
\end{gathered}
$$

where

$r(\mathbf{w})$ - the portfolio return,

E - the vector of expected pension funds returns,

$\beta \quad-$ the confidence level, $0<\beta<1$.

Conditional value at risk $(\mathrm{CVaR})$ is used as a measure of risk because it maintains advantages of value at risk $(\mathrm{VaR})$ and (2.1) becomes an LP-computable problem (Konno, Waki and Yukki, 2002). Black and Litterman (1991) developed a quantitative approach to deal with the problem of estimation error. The goal 
of this model is to create stable, mean-variance efficient portfolios, which overcomes the problem of input sensitivity. The Black-Litterman model uses ,equilibrium" returns as a neutral starting point. Equilibrium returns are calculated using either Capital Asset Pricing Model (CAPM) or reverse optimization method in which the vector of implied expected equilibrium returns $\mathbf{P}$ is extracted from known information and

$$
\mathbf{P}=\delta \mathbf{C w}
$$

where

w - in this case the vector of market capitalization weights,

C - the covariance matrix, $n \times n$, where $n$ is the number of assets,

$\delta$ - the risk-aversion coefficient, which represents the market average risk tolerance.

In general, the Black-Litterman approach consists of the following steps:

1. Define equilibrium market weights and covariance matrix for all asset classes.

2. Calculate the expected return implied from the market equilibrium portfolio.

3. Express market views and confidence for each view.

4. Calculate the view adjusted market equilibrium returns.

5. Run mean-variance optimization.

Following (Mitkova, Mlynarovic and Tus, 2007) the approach without market views expressions is used to describe the efficient frontier of the Slovak pension funds market in the following way. Let vector $\mathbf{w}_{\mathrm{c}}$ describe the capitalization on the market of the funds and $E_{c}$ is the corresponding return of the weighted market competition for the current period. The risk-adjusted return (R_A_R) can be written in the form

$$
E_{c}-\delta \mathbf{w}_{c}^{T} \mathbf{C} \mathbf{w}_{c}
$$

and it is assumed that this return is for the weighted market competition zero. So, we have

$$
\delta_{c}=\frac{E_{c}}{\mathbf{w}_{c}^{T} \mathbf{C} \mathbf{w}_{c}}
$$

and finally, the vector

$$
\mathbf{P}_{c}=\delta_{c} \mathbf{C} \mathbf{w}_{c}
$$

is used in

$$
f_{1}(\mathbf{w})=\mathbf{P}_{c}^{T} \mathbf{w}
$$

together with

$$
f_{2}(\mathbf{w})=\mathbf{w}^{T} \mathbf{C} \mathbf{w}
$$

in the resulting second version of the problem (2.1). 


\section{The Data and Legislative Changes}

The analysis is based on data of the Slovak National Bank reported daily for the second pillar (from April $1^{\text {st }}, 2005$ ) and for the third pillar (from July $1^{\text {st }}$, 2009) consists of funds income units and net assets values. The structure of the funds is described in Table 2. For the identification of the funds in this paper, the following structure of the funds' name is used: NAME_PILLAR_TYPE, where NAME consists of AEGON, ${ }^{2}$ Allianz, AXA, NN, PB, STB, VUB; PILLAR consists of DSS - second pillar, DDS - third pillar; and TYPE consists of C - conservative, B - balanced, G - growth, and I - index. There are included ten conservative funds, five balanced funds, and ten growth funds for the whole period. Also, five index funds for a shorter time, from April 2013 to June 2019. The value of the $\beta$ in this analysis was 0.98 .

T a b l e 2

\section{Pillars Notation}

\begin{tabular}{|l|l|l|l|l|}
\hline Pillar/type & Conservative & Balanced & Growth & Index $^{\mathbf{3}}$ \\
\hline DSS & AEGON & NN & Aegon & Aegon \\
(II. pillar) & Allianz & VUB & Allianz & AXA \\
& AXA & & AXA & PB \\
& PB & & PB & NN \\
& NN & & NN & VUB \\
& VUB & & VUB & \\
\hline DDS & AXA & AXA & AXA & \\
(III. pillar) & STB & STB & STB & \\
& PB & NN & PB & \\
& NN & & NN & \\
\hline
\end{tabular}

Source: Authors.

The legislative changes of the pension system of the Slovak Republic were analyzed on the conservative and growth pension funds operating during the complete period. Table 3 summarizes the legislative changes related to the pension funds in the second pillar. The changes are related to management companies on the one hand and savers on the other.

This part of the paper extends the research of Mlynarovic (2016). Three periods were set according to two main legislative changes, which, in our opinion, significantly influence the investment strategies of private pension funds and their positions on the efficient frontiers of the Slovak pension funds market. The first one on July 3, 2009, when the pension companies had to launch a guarantee fund for each of their pension investment funds, where flew all the yields. The yields were compared with a benchmark after six months with possible penalization of a pension company.

\footnotetext{
${ }^{2}$ From October 2019 included to NN (out of observed timespan).

${ }^{3}$ Data only for April 2013 to June 2019.
} 
T a ble 3

Legislative Changes of Slovak Pension System Review

\begin{tabular}{|c|c|c|c|c|}
\hline $\begin{array}{l}\text { With } \\
\text { effect } \\
\text { from }\end{array}$ & $\begin{array}{c}\text { Reward } \\
\text { to a pension } \\
\text { management } \\
\text { company }\end{array}$ & Entrance & Exit & Investment funds \\
\hline $\mathrm{I} / 2007$ & $0.065 \%$ & & & \\
\hline \multirow[t]{2}{*}{$\mathrm{I} / 2008$} & & $\begin{array}{l}\text { Possibility to enter } \\
\text { the second pillar till } \\
\text { june } 30,2008 \\
\end{array}$ & $\begin{array}{l}\text { Possibility to exit } \\
\text { to the first pillar }\end{array}$ & \\
\hline & & $\begin{array}{l}\text { Voluntary enter } \\
\text { for first-savers } \\
\end{array}$ & & \\
\hline $\mathrm{XI} / 2008$ & & $\begin{array}{l}\text { Possibility to enter } \\
\text { the second pillar till } \\
\text { june } 30,2009\end{array}$ & $\begin{array}{l}\text { Possibility to exit } \\
\text { to the first pillar till } \\
\text { june } 30,2009\end{array}$ & \\
\hline $\mathrm{I} / 2009$ & & & & $\begin{array}{l}\text { Reappraisal of limits and restrictions } \\
\text { for property disposals and reappraisal } \\
\text { of risk distribution rules }\end{array}$ \\
\hline \multirow[t]{2}{*}{ VII/2009 } & $0.025 \%$ & & & Guarantee fund \\
\hline & $\begin{array}{l}\text { The reward } \\
\text { for property } \\
\text { appraisal max } \\
5.6 \%\end{array}$ & & & \\
\hline \multirow[t]{6}{*}{ IV/2012 } & $\begin{array}{l}\text { High water } \\
\text { mark }\end{array}$ & $\begin{array}{l}\text { Automatic entry to } \\
\text { the second pillar for } \\
\text { first-savers (possible } \\
\text { exit within } 2 \text { years) }\end{array}$ & & $\begin{array}{l}\text { Mixed and stock funds: } \\
\text { end of property guarantees } \\
\text { Bond funds: a new form for } \\
\text { the guarantees } \\
\end{array}$ \\
\hline & \begin{tabular}{|l|} 
Reward lowers \\
the value of \\
the pension unit \\
\end{tabular} & & & $\begin{array}{l}\text { Mixed and stock funds: possibility } \\
\text { to invest into premium bonds for } \\
\text { precious metals, } \max 20 \%\end{array}$ \\
\hline & & & & $\begin{array}{l}\text { Stock funds: max } 80 \% \text { bonds } \\
\text { and money investments share } \\
\text { of the net value of property }\end{array}$ \\
\hline & & & & Possibility to choose a fund \\
\hline & & & & $\begin{array}{l}\text { Funds rename: conservative } \rightarrow \text { bond; } \\
\text { balanced } \rightarrow \text { mixed; growth } \rightarrow \text { equity; } \\
\text { and new index }\end{array}$ \\
\hline & & & & $\begin{array}{l}\text { Reference value - pension funds } \\
\text { yields and benchmark comparison }\end{array}$ \\
\hline $\mathrm{IX} / 2012$ & & $\begin{array}{l}\text { Possibility to enter } \\
\text { the second pillar till } \\
\text { january } 31,2013\end{array}$ & $\begin{array}{l}\text { Possibility to exit } \\
\text { to the first pillar till } \\
\text { january } 31,2013 \\
\end{array}$ & $\begin{array}{l}\text { Contribution rate to pension savings } \\
4 \% \text { ( } 9 \% \text { before) }\end{array}$ \\
\hline \multirow[t]{3}{*}{$\mathrm{I} / 2013$} & Max $0.3 \%$ & $\begin{array}{l}\text { Voluntary enter to } \\
\text { the second pillar till } \\
35 \text { years of age } \\
\text { (no exit option) }\end{array}$ & & $\begin{array}{l}\text { Guaranteed bond pension fund } \\
\text { (money and bond investments) } \\
\text { Non-guaranteed stock pension fund } \\
\text { (investment strategies related to } \\
\text { a wide variety of tolls including stocks) }\end{array}$ \\
\hline & $\begin{array}{l}\text { The reward } \\
\text { for property } \\
\text { Appraisal max } \\
10 \% \text { of } \\
\text { appraisal value } \\
\end{array}$ & & & \\
\hline & $\begin{array}{l}\text { The reward for } \\
\text { pension account } \\
\text { management } \\
\max 1 \% \\
\end{array}$ & & & \\
\hline $\mathrm{I} / 2017$ & & & & $\begin{array}{l}\text { Contribution rate to pension savings } \\
4.25 \% \text { ( } 4 \% \text { before) }\end{array}$ \\
\hline $\begin{array}{l}\mathrm{I} / 2018- \\
\mathrm{I} / 2024\end{array}$ & & & & $\begin{array}{l}\text { Contribution rate to pension savings } \\
\text { rises by } 0.25 \%\end{array}$ \\
\hline
\end{tabular}

Source: Own compilation based on information from National Bank of Slovakia. 
The conservative funds of the second pillar were under strict regulation with similar effects before 2009. It was analyzed whether the introduction of a guarantee account lowers the fund returns at a lower risk rate resulting in effective frontier movement closer to the origin in the equilibrium risk-return space. The second main change was on April 5, 2012, when pension management companies are obliged to administer two types of funds, a guaranteed conservative fund (now named bond fund) and an unguaranteed growth fund (now named equity fund). They can also run other types of guaranteed or unguaranteed funds (e.g. mixed). It means that guarantees for the other funds than conservative funds were canceled. The further analysis examines expected shifts of the effective frontiers toward the higher returns at higher risk. The notation of the funds is slightly changed to PERIOD_NAME_PILLAR_TYPE, where Period 0 tags March 22, 2006, till July 3, 2009, Period 1 tags July 3, 2009, till April 5, 2012, and Period 2 tags April 5, 2012, till June 28, 2019.

\section{The Results}

The conservative, balanced, and growth funds from the second and third pillars together were used to generate the effective frontier in CVaR-return space in Figure 1. This frontier is based on twenty-five pension funds' performance in the whole period as mentioned before. The return is measured by yearly moving average return and the risk by conditional value at risk. The graph depicts also indexed funds not included in the frontier generation since there are data available only for a shorter period.

Fig u re 1

\section{Effective Frontier in CVaR-return Space}

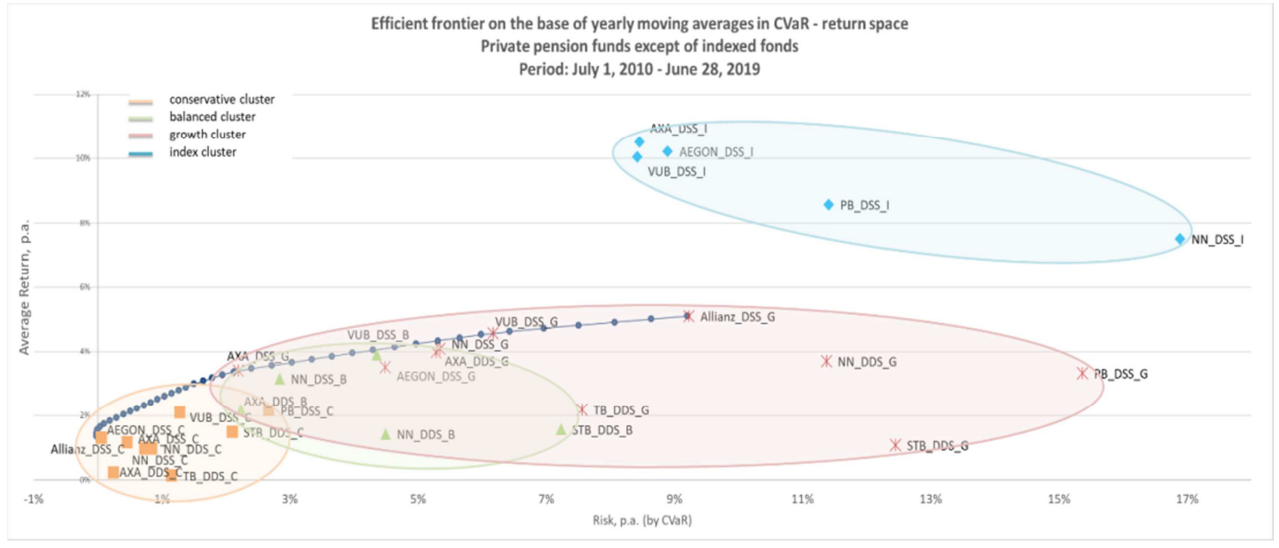

Source: Authors. 
To analyze the first question, just look at the position of each fund considering the effective frontier in Figure 1. Five pension funds are lying on the frontier: the conservative funds of Allianz and Aegon in the second pillar with low risk and return performance and three growth funds in the second pillar: AXA, VUB, and Allianz. Two growth funds of NN (second pillar), and AXA (third pillar) have a very close position to the frontier, and one balanced fund of VUB in the third pillar. Five out of ten examined conservative funds reach return below the effective frontier. The growth fund of STB in the third pillar achieves extremely low return along with a high risk rate.

The second question asks whether the outcomes of the investment strategies match the declared types. Figure 1 shows distinct clusters of three types of funds based on different investment strategies. The conservative funds perform with low return $(0-2.5 \%)$ and risk rates $(0-3 \%)$, as expected, and form a small compact cluster. The cluster of balanced funds shows higher diversity in risk $(2-7.5 \%)$ with two funds close to the frontier and two funds with relatively low (below minimal accepted) return $(0-4 \%)$. This set is almost completely a part of the growth funds cluster showing that the growth funds' cluster has nearly the same returns $(1-5 \%)$ with the highest spread in risk (with several „outsiders“: AXA and PB in the second pillar. The picture also captures the indexed funds' cluster, separate from the previous three.

Next, the same analysis was performed in a shorter time span, where the returns for index funds are available. The effective frontier in return $-\mathrm{CVaR}$ was generated for thirty pension funds from April 25, 2013, till June 28, 2019. Figure 2 proves the results of the previous part of the research. Moreover, the index funds create a separate cluster with the highest return and comparable risk rate of growth funds, with performance near the effective frontier.

The effect of legislative changes was examined by using the model (2.11 2.12) and corresponding efficient frontiers are constructed under the condition of existence of two fictive funds (MC_sa) using simple average returns and (MC_wa) using weighted average returns. The risk, equilibrium return, market weights, risk-adjusted return (R_A_R), and equilibrium return/risk ratio are calculated for the second pillar conservative (Table 4) and growth funds (Table 5) including two fictive funds. The R_A_R for weighted market competition (MC_wa) is by definition (2.8) equal to zero which allows separating the funds on a given market on relatively ,good“ with a positive value and relatively „bad“ with a negative value. The equilibrium return/risk ratio value allows outranking the funds as well. Figure 3 depicts the effective frontiers in expected equilibrium risk-return measured by standard deviation space for conservative funds in base Period 0 , Period 1, and Period 2. Figure 4 shows the same for the growth funds. 
Figure 2

Efficient Frontier in CVaR-return Space in a Shorter Time

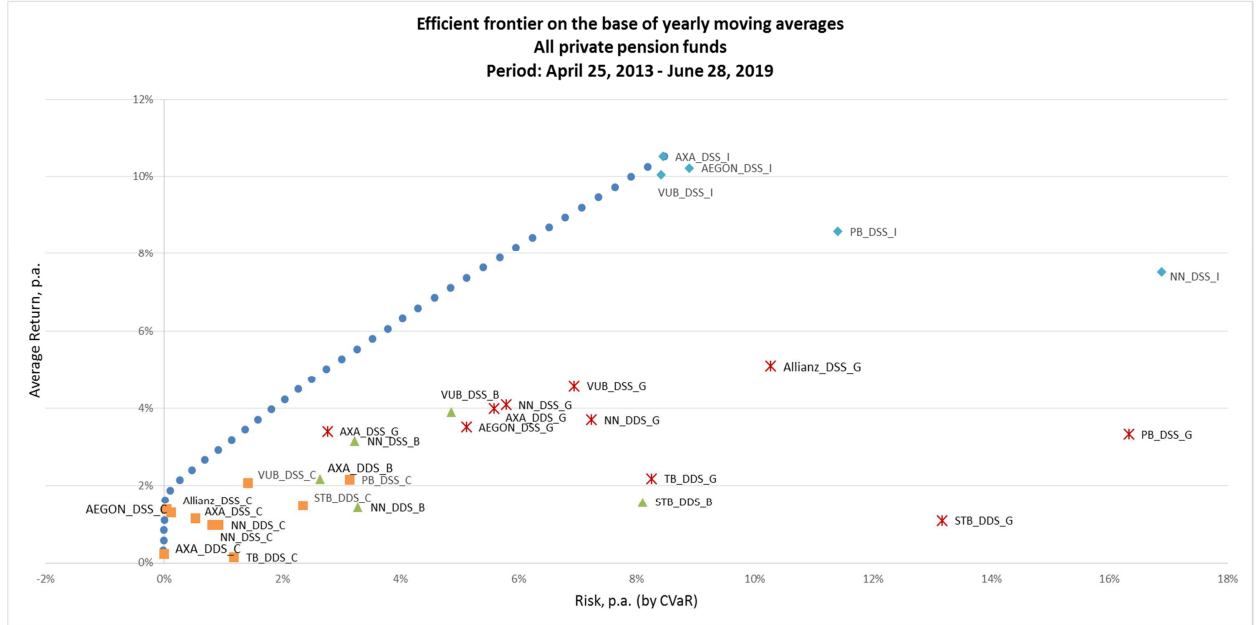

Source: Authors.

Fig u re 3

Efficient Frontiers for Conservative Funds in Three Periods

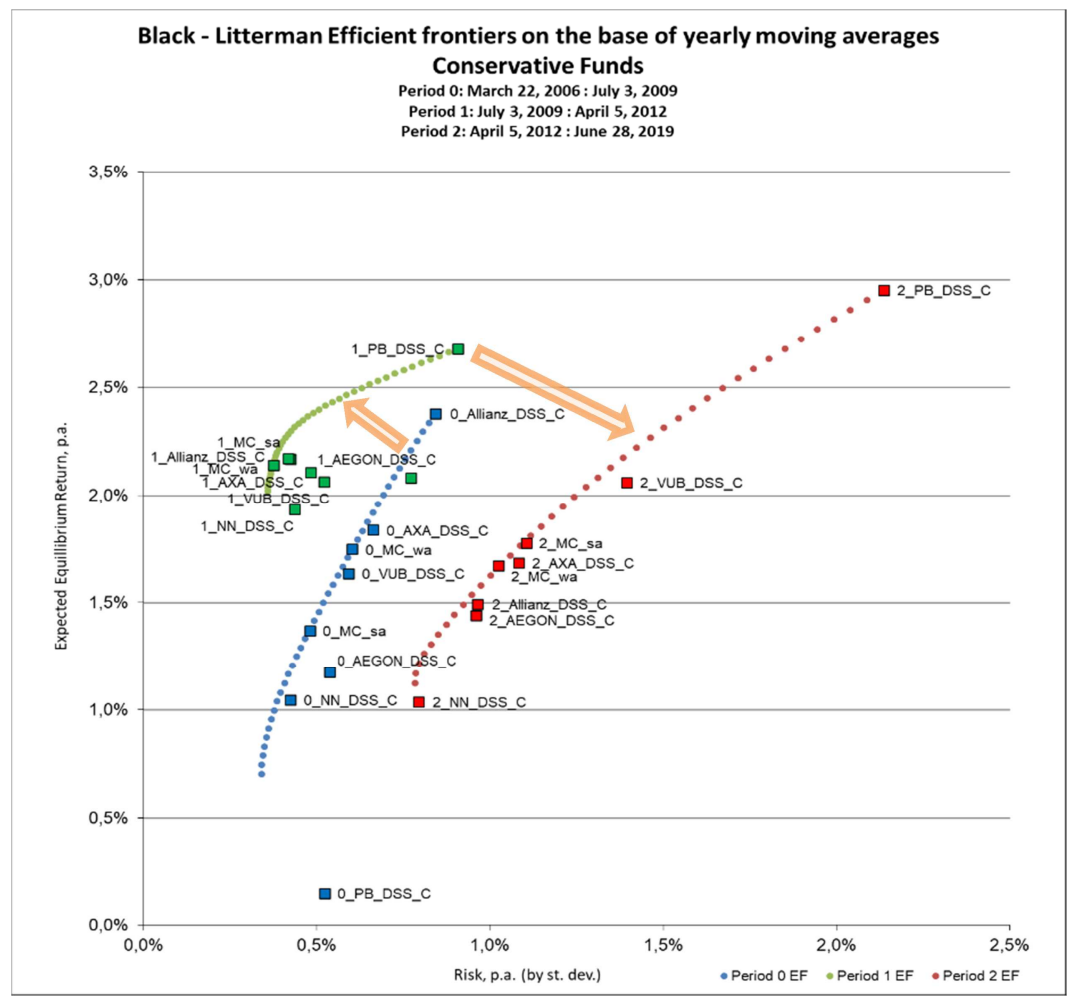

Source: Authors. 


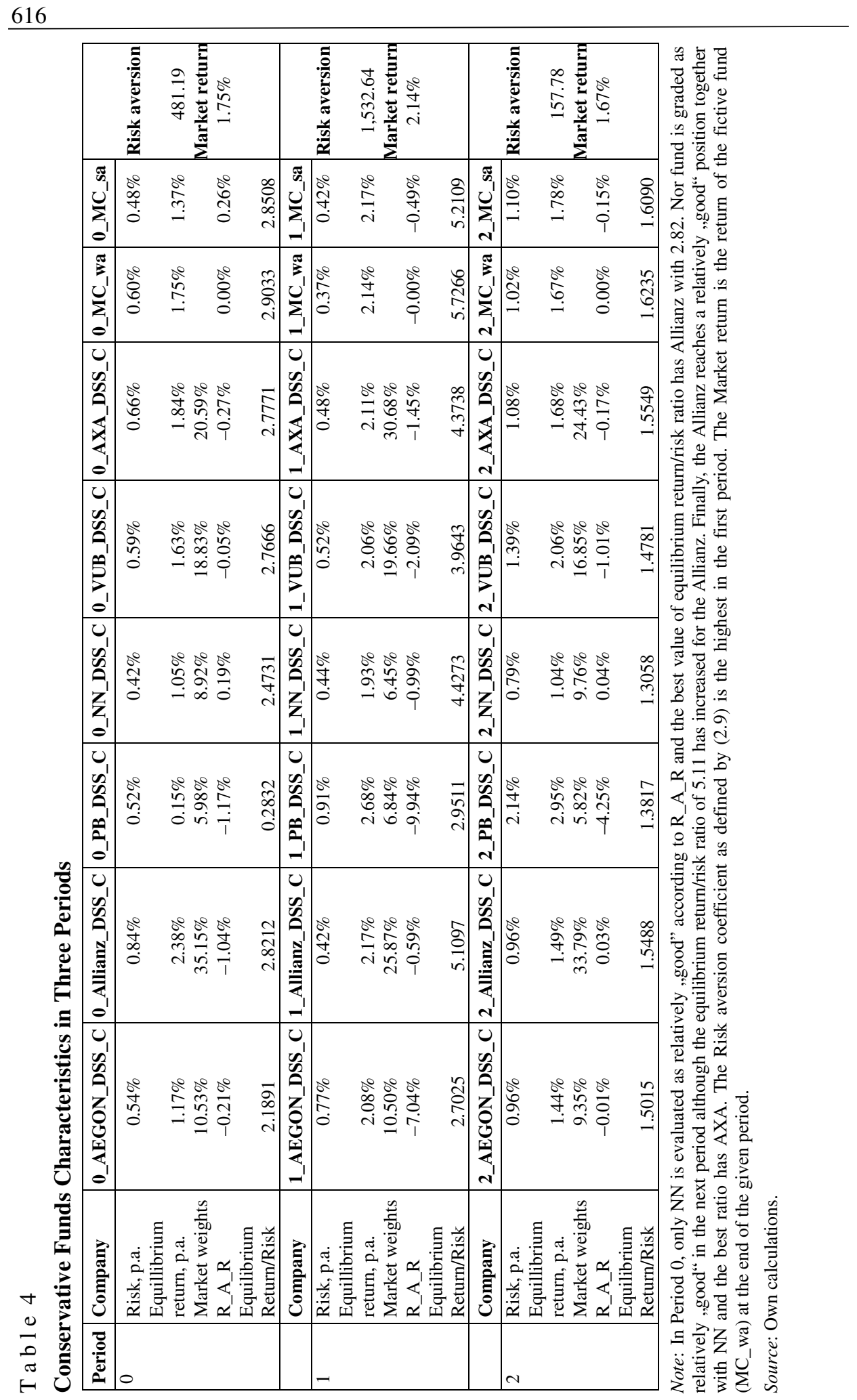




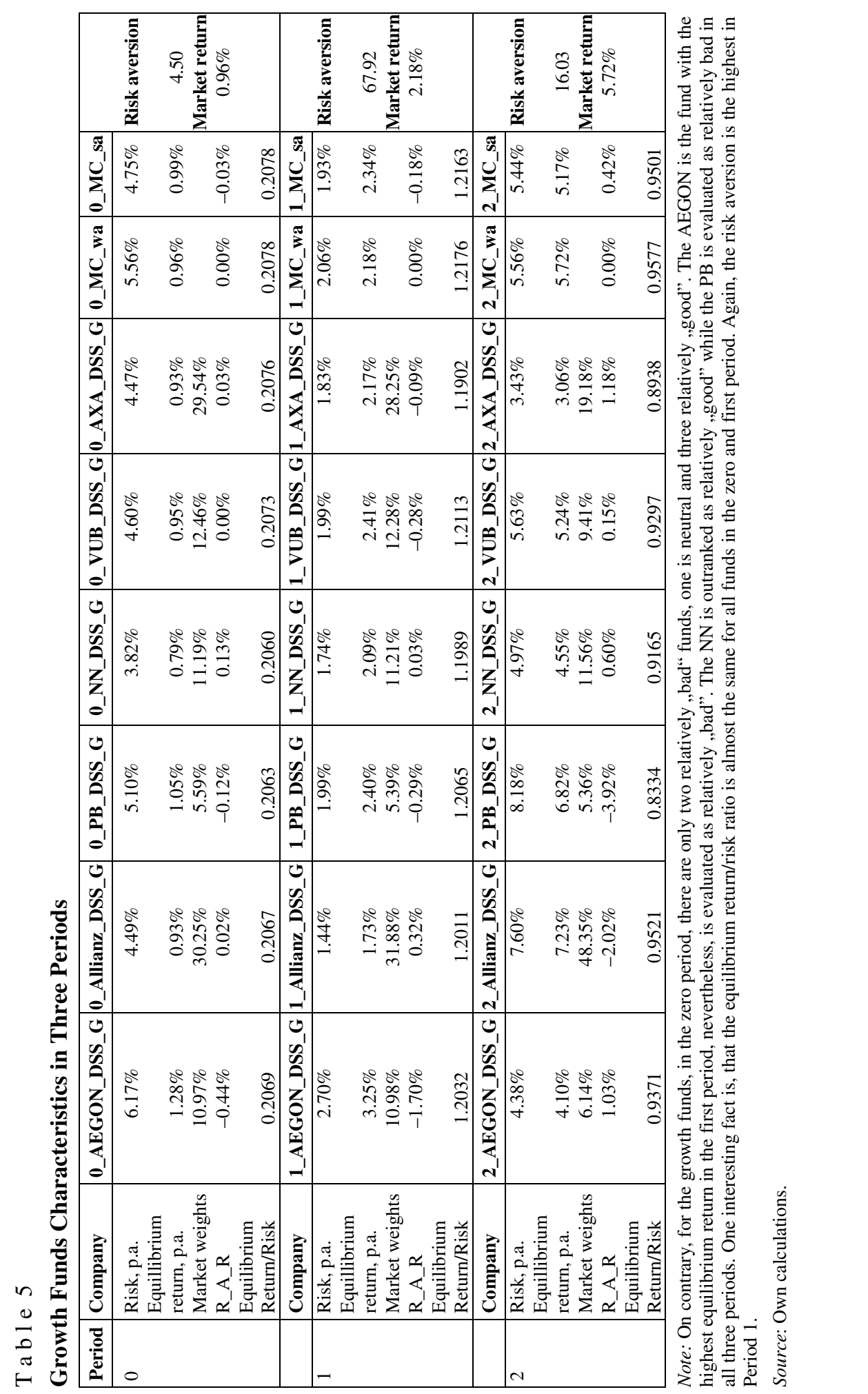


It was expected that the introduction of a guarantee account in July 2009 lowers the fund returns at a lower risk rate resulting in effective frontier movement closer to the origin in the equilibrium risk-return space. The arrangement in April 2012 was expected to relax the risk rate, hence shift the effective frontier toward higher returns at higher risk. Figure 3 shows the effective frontier shifts from the base Period 0. The first significant legislative change in July 2009 resulted in the upper-left movement of the effective frontier for conservative funds toward higher expected returns at lower risk rates. The second substantial change in pension funds legislative in April 2012 caused down-right movement of the effective frontier, even further as at the initial conditions.

Figure 4

\section{Efficient Frontiers for Growth Funds in Three Periods}

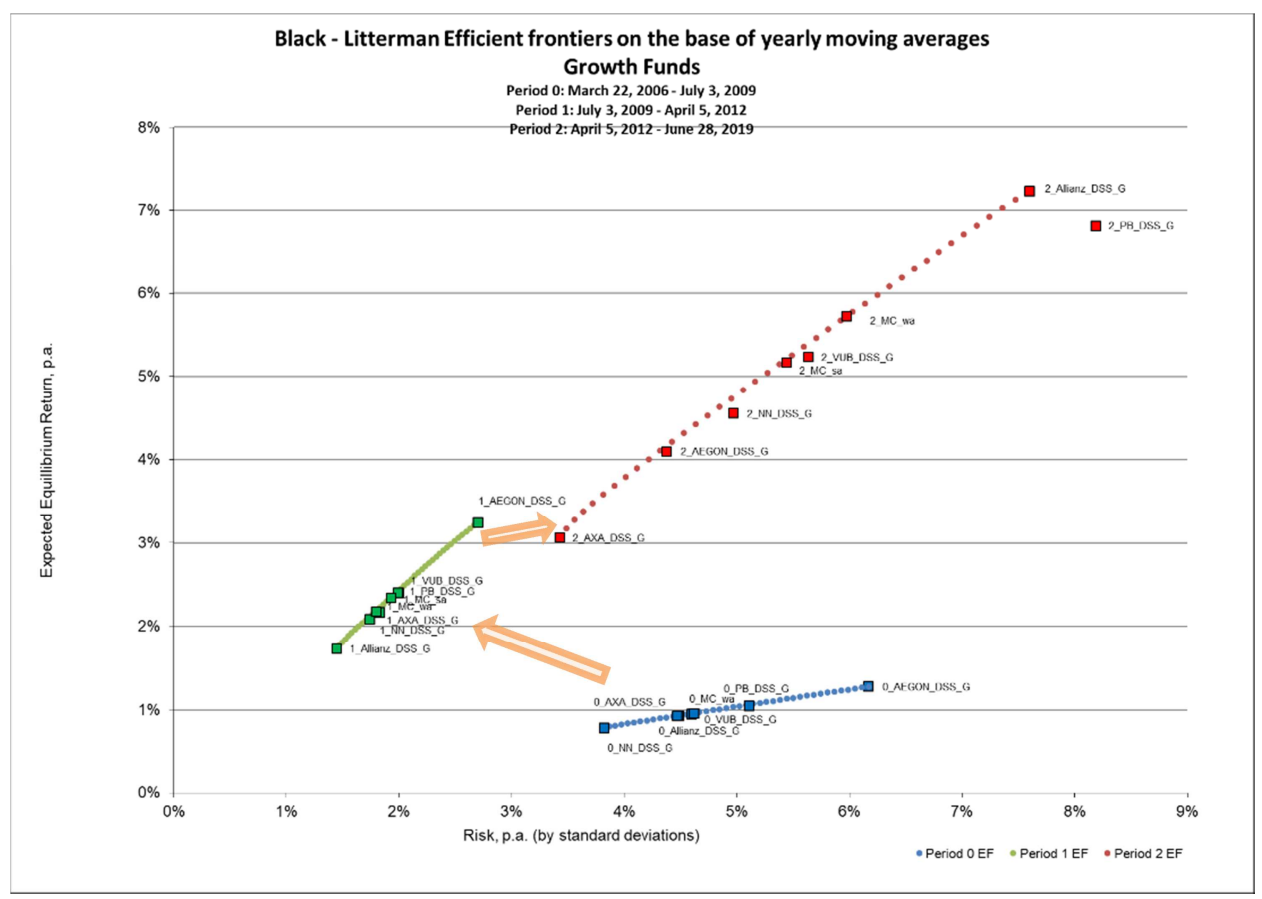

Source: Authors.

For the growth funds, the effective frontier of Period 1 substantially increased the expected equilibrium returns at lower risk rates. The guarantees regulation release in the second period resulted in an effective frontier shift to higher returns and higher risk rates compared to the situation before any government regulation.

The third non-compulsory pillar is not subject to such rigorous government regulations and legislative changes. The motivation for reviewing this sector of the pension funds market is the comparison of the portfolio managers' decisions 
not underlying the legislative changes for the second pillar. The same analysis was conducted for the third pillar funds where four conservative funds and subsequently four growth funds were included in this analysis. Period 1 and Period 2 were examined for the complete dataset of the third pillar.

Table 6 and Figure 5 are related to the conservative funds and depict the effective frontier movement towards lower expected equilibrium returns at a higher risk rate in Period 2. The shift of the effective frontier for the third pillar tracks the shift of the second pillar direction.

Figure 5

Effective Frontier of the Conservative Funds of the Third Pillar

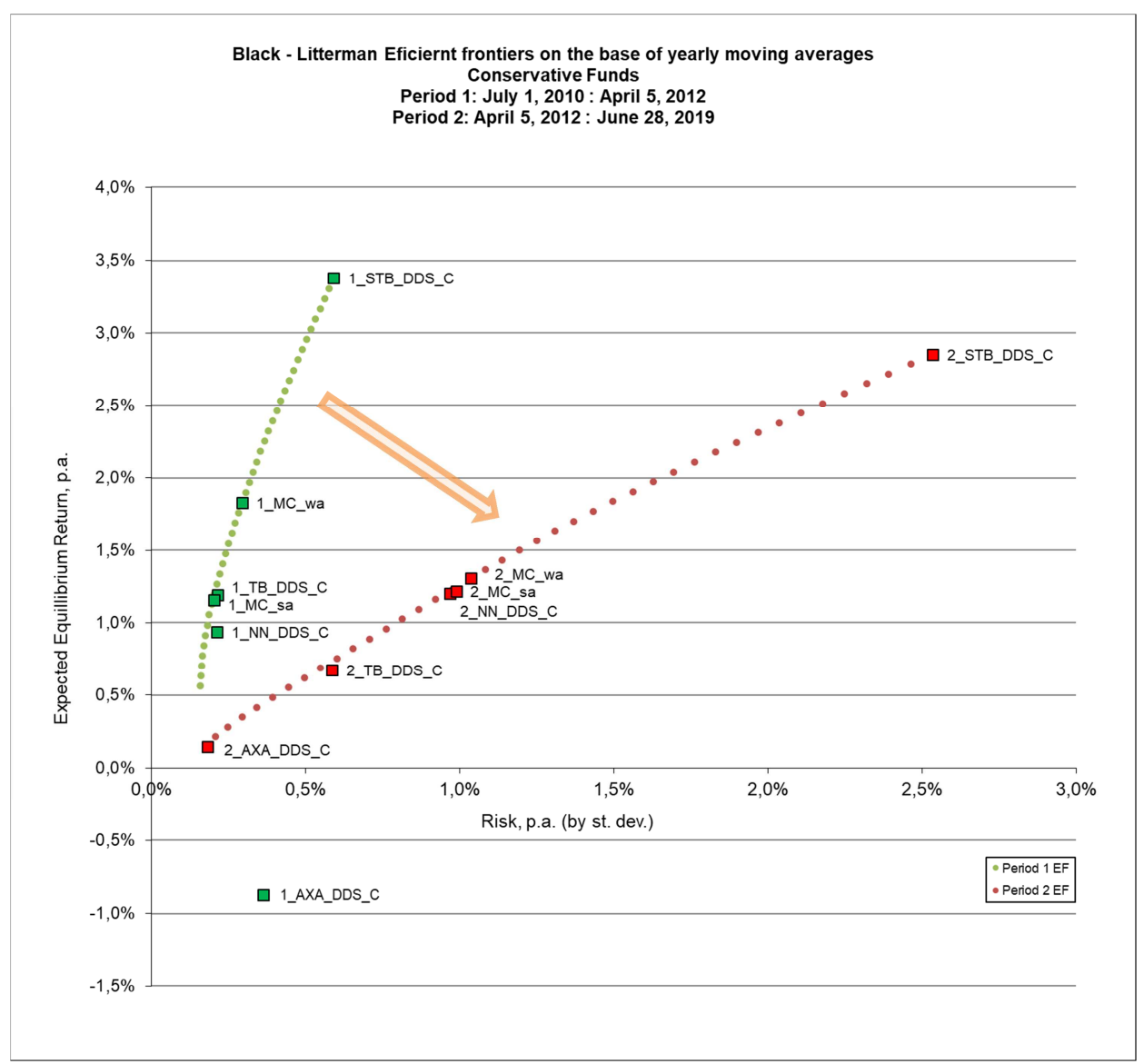

Source: Authors.

Table 6 shows that the highest equilibrium return among conservative funds in the third pillar had STB, it was accompanied with the highest risk in both periods, and the fund was evaluated as the only relatively „bad“ fund in Period 2. 
The AXA had an even negative equilibrium return in the first period. The risk aversion substantially decreased in the second period.

T a ble 6

\section{Third Pillar Conservative Funds Characteristics}

\begin{tabular}{|c|c|c|c|c|c|c|c|c|}
\hline Period & Company & 1_AXA_- & $\begin{array}{l}\text { 1_TB_E } \\
\text { DDS_C }\end{array}$ & $\begin{array}{l}\text { 1_NN_ } \\
\text { DDS_C }\end{array}$ & 1_STB_- & 1_MC_wa & 1_MC_sa & \\
\hline 1 & $\begin{array}{l}\text { Risk, p.a. } \\
\text { Equillibrium return, p.a. } \\
\text { Market weights } \\
\text { R_A_R } \\
\text { Equilibrium Return/Risk }\end{array}$ & $\begin{array}{r}0.36 \% \\
-0.87 \% \\
0.35 \% \\
-3.65 \% \\
-2.3934\end{array}$ & $\begin{array}{r}0.22 \% \\
1.19 \% \\
15.68 \% \\
0.22 \% \\
5.5440\end{array}$ & \begin{tabular}{r|}
$0.21 \%$ \\
$0.94 \%$ \\
$48.74 \%$ \\
$-0.01 \%$ \\
4.4025 \\
\end{tabular} & $\begin{array}{r}0.59 \% \\
3.38 \% \\
35.23 \% \\
-3.97 \% \\
5.7104\end{array}$ & $\begin{array}{r}0.30 \% \\
1.83 \% \\
\\
0.00 \% \\
6.1987\end{array}$ & $\begin{array}{r}0.20 \% \\
1.16 \% \\
\\
0.29 \% \\
5.7062\end{array}$ & \begin{tabular}{|c|} 
Risk aversion \\
$2,099.49$ \\
Market return \\
$1.83 \%$
\end{tabular} \\
\hline & Company & $\underset{\text { DDS_C }}{\text { 2_AXA }}$ & $\begin{array}{l}\text { 2_TB_- } \\
\text { DDS_C }\end{array}$ & $\begin{array}{l}\text { 2_NN_ } \\
\text { DDS_C }\end{array}$ & $\begin{array}{l}\text { 2_STB_- } \\
\text { DDS_C }\end{array}$ & 2_MC_wa & 2_MC_sa & \\
\hline$\left.\right|^{2}$ & $\begin{array}{l}\text { Risk, p.a. } \\
\text { Equillibrium return, p.a. } \\
\text { Market weights } \\
\text { R_A_R } \\
\text { Equilibrium Return/Risk }\end{array}$ & $\begin{array}{l}0.18 \% \\
0.14 \% \\
3.48 \% \\
0.10 \% \\
0.79\end{array}$ & $\begin{array}{r}0.59 \% \\
0.67 \% \\
10.87 \% \\
0.25 \% \\
1.14\end{array}$ & $\begin{array}{r}0.97 \% \\
1.20 \% \\
73.52 \% \\
0.06 \% \\
1.24\end{array}$ & $\begin{array}{r}2.54 \% \\
2.85 \% \\
12.13 \% \\
-4.94 \% \\
1.13\end{array}$ & $\begin{array}{l}1.04 \% \\
1.31 \% \\
0.00 \% \\
1.26\end{array}$ & $\begin{array}{l}0.99 \% \\
1.22 \% \\
0.03 \% \\
1.23\end{array}$ & \begin{tabular}{|c|} 
Risk aversion \\
121.30 \\
Market return \\
$1.31 \%$
\end{tabular} \\
\hline
\end{tabular}

Source: Own calculations.

Table 7 and Figure 6 are related to the growth funds of the third pillar. In Period 2, the effective frontier exhibits higher expected returns at almost the same risk rate as in Period 1. Compared to the second pillar evolution, the shift of the effective frontier for the third pillar hereby does not follow the second pillar direction.

T a b l e 7

Third Pillar Growth Funds Characteristics

\begin{tabular}{|c|c|c|c|c|c|c|c|c|}
\hline Period & Company & \begin{tabular}{|l|} 
1_AXA_- \\
DDS_G
\end{tabular} & $\begin{array}{l}\text { 1_TB_T } \\
\text { DDS_G }\end{array}$ & \begin{tabular}{|l|} 
1_NN_N \\
DDS_G
\end{tabular} & \begin{tabular}{|l|} 
1_STB_- \\
DDS_G
\end{tabular} & 1_MC_wa & 1_MC_sa & \multirow[b]{2}{*}{$\begin{array}{c}\text { Risk aversion } \\
9.16 \\
\text { Market return } \\
1.67 \%\end{array}$} \\
\hline \multirow[t]{2}{*}{1} & $\begin{array}{l}\text { Risk, p.a. } \\
\text { Equillibrium return, p.a. } \\
\text { Market weights } \\
\text { R_A_R } \\
\text { Equilibrium Return/Risk } \\
\end{array}$ & \begin{tabular}{|r|}
$3.63 \%$ \\
$1.39 \%$ \\
$16.25 \%$ \\
$0.18 \%$ \\
0.3834 \\
\end{tabular} & \begin{tabular}{|c|}
$3.91 \%$ \\
$1.52 \%$ \\
$67.80 \%$ \\
$0.12 \%$ \\
0.3889 \\
\end{tabular} & \begin{tabular}{|r|}
$6.81 \%$ \\
$2.60 \%$ \\
$15.67 \%$ \\
$-1.65 \%$ \\
0.3818 \\
\end{tabular} & \begin{tabular}{|r|}
$4.16 \%$ \\
$1.21 \%$ \\
$0.28 \%$ \\
$-0.37 \%$ \\
0.2922 \\
\end{tabular} & $\begin{array}{c}4.27 \% \\
1.67 \% \\
\\
0.00 \% \\
0.3911 \\
\end{array}$ & \begin{tabular}{|c|}
$4.39 \%$ \\
$1.68 \%$ \\
\\
$-0.09 \%$ \\
0.3830 \\
\end{tabular} & \\
\hline & Company & $\mid$\begin{tabular}{|} 
2_AXA_A \\
DDS_G
\end{tabular} & $\mid \begin{array}{l}2 \_ \text {TB_ } \\
\text { DDS_G }\end{array}$ & $\mid \begin{array}{l}\text { 2_NN_N } \\
\text { DDS_G }\end{array}$ & $\begin{array}{l}\text { 2_STB } \\
\text { DDS_G }\end{array}$ & 2_MC_wa & 2_MC_sa & \multirow[b]{2}{*}{\begin{tabular}{|c|} 
Risk aversion \\
12.54 \\
Market return \\
$3.00 \%$
\end{tabular}} \\
\hline 2 & $\begin{array}{l}\text { Risk, p.a. } \\
\text { Equillibrium return, p.a. } \\
\text { Market weights } \\
\text { R_A_R } \\
\text { Equilibrium Return/Risk }\end{array}$ & \begin{tabular}{|r|}
$4.90 \%$ \\
$2.52 \%$ \\
$22.97 \%$ \\
$-0.49 \%$ \\
0.51 \\
\end{tabular} & \begin{tabular}{|r|}
$4.64 \%$ \\
$2.64 \%$ \\
$44.71 \%$ \\
$-0.06 \%$ \\
0.57 \\
\end{tabular} & \begin{tabular}{|r|}
$6.93 \%$ \\
$3.98 \%$ \\
$26.14 \%$ \\
$-2.04 \%$ \\
0.57 \\
\end{tabular} & $\begin{array}{r}6.09 \% \\
3.19 \% \\
6.18 \% \\
-1.46 \% \\
0.52\end{array}$ & $\begin{array}{l}4.89 \% \\
3.00 \% \\
\\
0.00 \% \\
0.61 \\
\end{array}$ & $\begin{array}{c}5.10 \% \\
3.08 \% \\
\\
-0.18 \% \\
0.60 \\
\end{array}$ & \\
\hline
\end{tabular}

Source: Own calculations.

The risk aversion for growth funds does not differ considerably in the two periods. The equilibrium return/risk ratio grows in the second period for all funds, although all the funds are evaluated as relatively „bad”. 
Figure 6

\section{Effective Frontier of the Growth Funds of the Third Pillar}

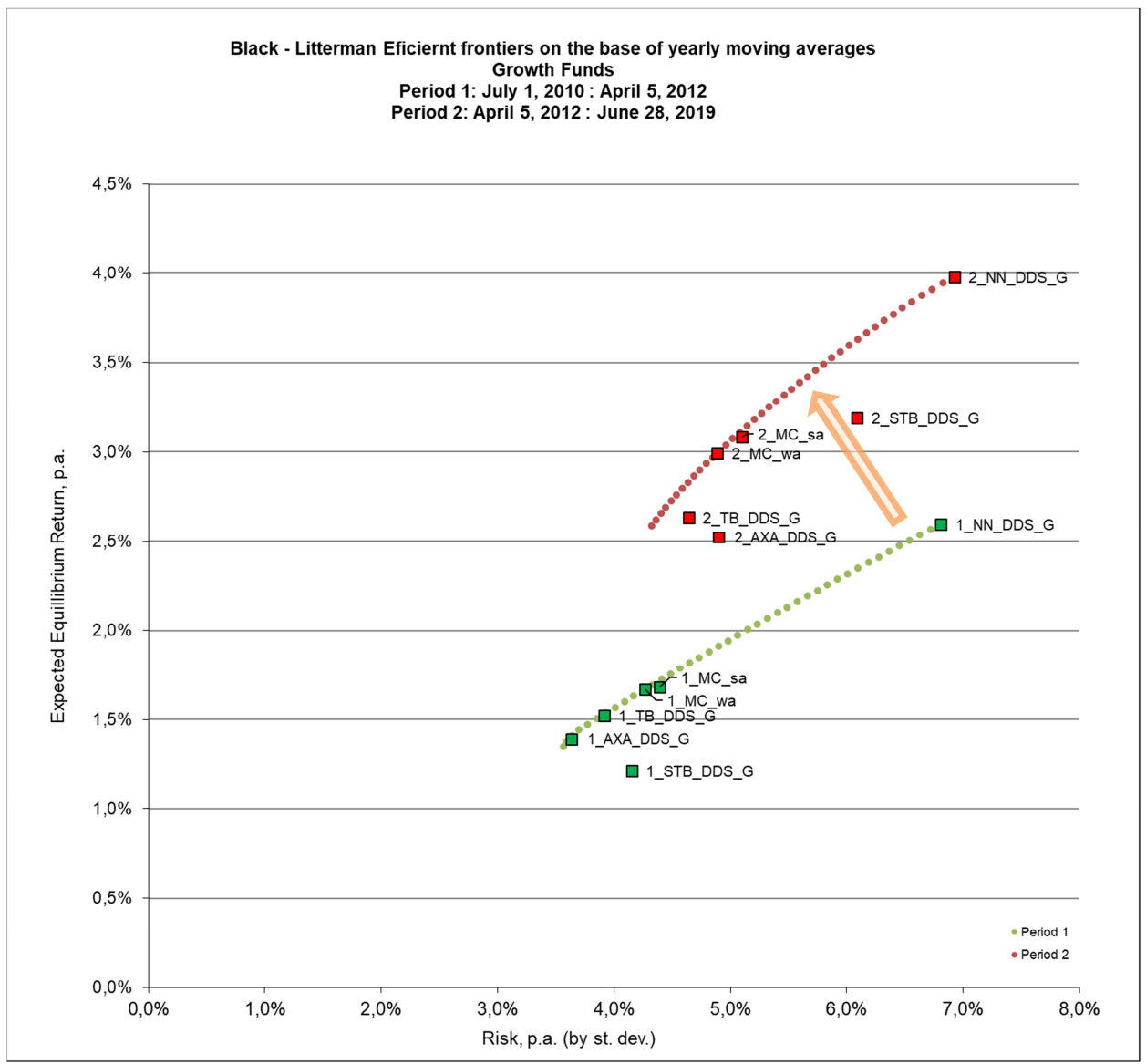

Source: Authors.

\section{Conclusions}

The private Slovak pension system market consists of the first pillar, the second pillar, and the voluntary third pillar. The focus was on the second and third pillars in this analysis. In the first part of the research, the two main questions were answered. Two separate analyses were conducted to evaluate the efficiency of single pension funds in CVaR-return space, one for the whole time span from March 22, 2006, till June 28, 2019, for twenty-five private pension funds of conservative, balanced, and growth strategies (the index funds not included to the frontier creation) and the second for the whole market on shorter timespan from April 25, 2013, till June 28, 2019, for thirty private pension funds for the previous three strategies plus indexed funds. To answer the first question of how 
effective the strategy of the single pension fund is; let's find its position towards the effective frontier: conservative funds of Allianz and Aegon in the second pillar and AXA, VUB, and Allianz growth funds in the third pillar lye on the frontier. Another two funds lie very close to it: the second pillar growth fund of $\mathrm{NN}$, the third pillar growth fund of AXA, and the third pillar balanced fund of VUB. On contrary, the growth fund of STB in the third pillar performs on very low return and high risk rate.

The second question, whether the investment strategies outcomes match the declared types of four strategies, was answered through clusters formation in the CVaR-return space for the whole period. It is expected that the conservative funds generate a cluster at a low risk-return rate, the balanced funds cluster with a higher rate, and finally, the growth funds the highest risk-return rate cluster. The conservative funds form a small compact cluster and fulfill the expectations. The balanced funds generate a cluster with a higher risk-return rate, exactly as expected. The growth funds exhibit a high spread in risk rate and almost completely overlap the balanced funds' cluster. It was definitely proved that the outcomes of conservative, balanced, and index pension funds match the declared types of strategies and the growth funds do not clearly differentiate its outcomes. The indexed funds added to the analysis form cluster at the highest risk-return as expected. The second part of the analysis carried out with all private pension funds in a shorter time proves the conclusions of the previous one.

Since the Slovak pension system was reformed several times, the portfolios in the second pillar were managed under changing strict legislative restrictions. The legislative changes impact on the conservative and growth pension investment funds strategies in the second and third pillars was examined in the final part of the paper. Very cautious investment strategies were set at the beginning of the private pension funds' existence (the period from 2006 to 2009) causing comparable expected returns and risks for the conservative and growth funds. In July 2009 there was introduced a guarantee fund for the second pillar funds hence the portfolio managers of the growth funds were aware of higher returns because they had to guarantee them for the future based on the six months moving average returns. The period of six months was considered by the portfolio managers as too short to manage the high volatility of returns of the risky assets, hence they lowered the risk structure of the growth funds. This holds till April 2012 when the guarantees were relaxed for the growth funds. Next, the growth funds strategies moved towards higher returns as is seen in Figure 3. The third pillar does not underlie these regulations. The government regulation in the first period caused the effective frontier for conservative funds to shift towards the higher expected returns at near the same risk rate as before. The conservative funds in 
the next period were not under relaxed regulation, regardless the effective frontier shifted to a higher risk rate with larger dispersion of the expected returns. The effective frontier in the third pillar not strictly regulated conservative funds market shows the same shift between the first and second period. The growth funds performance was analyzed further. The guarantee fund established for the second pillar resulted in a significant shift of the effective frontier towards higher returns at lower risk, subsequently, relaxation of this regulation caused its shift towards higher expected returns at a slightly higher risk rate compared to the pre-regulation period. The third pillar growth funds at the same time increased the expected returns at similar risk rates. We can conclude that the investment strategies of the growth funds were influenced by the legislative changes.

Our conclusion shows that the process of legislative changes does not indicate the risk lowering in general, although the analysis of Kilianova, Melichercik and Sevcovic (2006) from the beginning of the reformed pension system in Slovakia proved that there is a reasonable risk decline supported by legislation changes. There is an idea for future research to analyze the individual clients' decisions in the context of the pension funds legislative changes.

\section{References}

ADEMA, Y. - MEIJDAM, L. - VERBON, H. A. A. (2009): The International Spillover Effects of Pension Reform. International Tax and Public Finance, 16, No. 5, pp. 670 - 696. DOI: 10.1007/s10797-008-9084-x.

ANGELIDIS, T. - TESSAROMATIS, N. (2010): The Efficiency of Greek Public-pension Fund Portfolios. Journal of Banking and Finance, 34, No. 9, pp. 2158 - 2167. DOI: $10.2139 / \mathrm{ssrn} .1394457$.

ARTUS, P. (2000): Pension Funds Ask for Very High Returns: What are the Effects of that Behavior on the Efficiency and the Stability of the Economies? Revue Economique, 51, Special issue, pp. $31-54$.

BARROS, C. P. - GARCIA, M. T. M. (2007): Analysing the Performance of the Pension Fund Industry with a Stochastic Frontier Model: A Case Study for Portugal. Geneva Papers on Risk and Insurance - Issues and Practice, 32, No. 2, pp. 190 - 210.

BERTSIMAS, D. - GUPTA, V. - PASCHALIDIS, I. C. (2012): Inverse Optimization: A New Perspective on the Black-Litterman Model. Operations Research, 60, No. 6, pp. $1389-1403$. DOI: $10.2307 / 23323707$.

BESSLER, W. - OPFER, H. - WOLFF, D. (2017): Multi-asset Portfolio Optimization and Out-ofsample Performance: An Evaluation of Black-Litterman, Mean-variance, and Naive Diversification Approaches. European Journal of Finance, 23, No. 1, pp. 1 - 30. DOI: $10.2139 /$ ssrn.2081636.

BIAN, L. - LI, Z. - YAO, H. (2018): Pre-commitment and Equilibrium Investment Strategies for the DC Pension Plan with Regime Switching and a Return of Premium Clause. Insurance Mathematics and Economics, 81, pp. 78 - 94. DOI: 10.1016/j.insmatheco.2018.05.005.

BLACK, F. - LITTERMAN, R. (1991): Asset Allocation: Combining Investor Views with Market Equilibrium. The Journal of Fixed Income, 1, No. 2, pp. 7 - 18. Available at: <https://doi.org/10.3905/jfi.1991.408013>. 
BOTTAZZI, R. - JAPPELLI, T. - PADULA, M. (2011): The Portfolio Effect of Pension Reforms: Evidence from Italy. Journal of Pension Economics and Finance, 10, No. 1, pp. 75 - 97. Available at: 〈https://doi.org/10.1017/S147474721000003X〉.

CASARICO, A. (1998): Pension Reform and Economic Performance under Imperfect Capital Markets. Economic Journal, 108, No. 447, pp. 344 - 362. Available at: <https://doi.org/10.1111/1468-0297.00291>.

COBOVIC, M. V. - COBOVIC, M. (2016): Sustainability of Pension Insurance System in Republic of Croatia. Osijek: Croatia, pp. $840-848$.

DA SILVA, A. S. - LEE, W. - PORNROJNANGKOOL, B. (2009): The Black-Litterman Model for Active Portfolio Management. Journal of Portfolio Management, 35, No. 2, pp. 61 - 70. DOI: 10.3905/JPM.2009.35.2.061.

DE LA TORRE-TORRES, O. V. - GALEANA-FIGUEROA, E. - ALVAREZ-GARCIA, J. (2019): Efficiency of the Public Pensions Funds on the Socially Responsible Equities of Mexico. Sustainability, 11, No. 1, Article number 178. Available at: 〈https://doi.org/10.3390/su11010178>.

FEHR, H. (1999): Privatization of Public Pensions in Germany: Who Gains and How Much? Jahrbucher fur Nationalokonomie ud Statistik, 218, No. 5 - 6, pp. 674 - 694. Available at: <https://doi.org/10.1515/jbnst-1999-5-609>.

FEHR, H. (2009): Computable Stochastic Equilibrium Models and Their Use in Pension- and Ageing Research. Economist - Netherlands, 157, No. 4, pp. 359 - 416. DOI: 10.1007/s10645-009-9131-8.

FEHR, H. (2016): CGE Modeling Social Security Reforms. Journal of Policy Modeling, 38, No. 3, pp. 475 - 494. DOI: 10.1016/j.jpolmod.2016.02.007.

FOO, J. - WITKOWSKA, D. (2016): Investment Performance of US and European Pension Funds. A Comparative Analysis. Aestimation - The IEB International Journal of Finance, 13, pp. 90 - 109. DOI: 10.5605/IEB.13.

GARCIA, M. T. M. (2010): Efficiency Evaluation of the Portuguese Pension Funds Management Companies. Journal of International Financial Markets Institutions and Money, 20, No. 3, pp. 259 - 266. DOI: 10.1016/j.intfin.2010.03.003.

GNEDENKO, B. - YELNIK, I. (2016): Reconciling Factor Optimization with Portfolio Constraints. Journal of Investment Strategies, 5, No. 3, pp. 39 - 50. DOI: 10.21314/JOIS.2016.069.

GOKCEN, U. - YALCIN, A. (2015): The Case against Active Pension Funds: Evidence from the Turkish Private Pension System. Emerging Markets Review, 23, No. C, pp. 46 - 67. DOI: 10.1016/j.ememar.2015.04.007.

GOKGOZ, F. (2010): Measuring the Financial Efficiencies and Performances of Turkish Funds. Acta Oeconomica, 60, No. 3, pp. 295 - 320. DOI: 10.1556/AOecon.60.2010.3.4.

GUARDIANCICH, I. (2011): Pan-European Pension Funds: Current Situation and Future Prospects. International Social Security Review, 64, No. 1, pp. 15 - 36. DOI: $10.1111 /$ j.1468-246X.2010.01382.x.

HURLEY, W. J. - BRIMBERG, J. (2015): A Note on the Sensitivity of the Strategic Asset Allocation Problem. Operations Research Perspectives, 2, December, pp. 133 - 136. Available at: <https://doi.org/10.1016/j.orp.2015.06.003>.

CHEUNG, W. (2010): The Black-Litterman Model Explained. Journal of Asset Management, 11, No. 4, pp. 229 - 243. DOI: 10.1057 jam.2009.28.

CHOPRA, V. K. (1993): Improving Optimization. The Journal of Investing, 2, No. 3, pp. 51 - 59. Available at: 〈https://doi.org/10.3905/joi.2.3.51〉.

JAKUBIK, T. - MELICHERCIK, I. - SEVCOVIC, D. (2009): Sensitivity Analysis for a Dynamic Stochastic Accumulation Model for Optimal Pension Savings Management. Ekonomický časopis/ Journal of Economics, 57, No. 8, pp. $756-771$.

JAYEOLA, D. - ISMAIL, Z. (2018): Impacts of Riskless Assets on Diversification. Advanced Science Letters, 24, No. 6, pp. $4286-4289$.

JAYEOLA, D. - ISMAIL, Z. - SUFAHANI, S. F. (2017): Effects of Diversification of Assets in Optimizing Risk of Portfolio. Malaysian Journal of Fundamental and Applied Science, 13, No. 4, pp. $584-587$. 
JIA, X. - GAO, J. (2016): Extensions of Black-Litterman Portfolio Optimization Model with Downside Risk Measure. In: Chinese Control and Decision Conference. Yinchuan, China, pp. 1114 - 1119. DOI: 10.1109/CCDC.2016.7531150.

JONES, R. - LIM, T. - ZANGARI, P. J. (2007): The Black-Litterman Model for Structured Equity Portfolios - Using Views Based on Factors to Construct Equity Portfolios. Journal of Portfolio Management, 33, No. 2, pp. 24 - 33. Available at: 〈https://doi.org/10.3905/jpm.2007.674791〉.

KARA, M. - ULUCAN, A. - ATICI, K. B. (2019): A Hybrid Approach for Generating Investor Views in Black-Litterman Model. Expert Systems with Applications, 128, August, pp. 256 - 270. Available at: <https://doi.org/10.1016/j.eswa.2019.03.041>.

KILIANOVA, S. - MELICHERCIK, I. - SEVCOVIC, D. (2006): Dynamic Accumulation Model for the Second Pillar of the Slovak Pension System. Finance a uver, 56, No. $11-12$, pp. $506-521$.

KOLM, P. N. - TUTUNCU, R. - FABOZZI, F. J. (2014): 60 Year of Portfolio Optimization: Practical Challenges and Current Trends. European Journal of Operational Research, 234, No. 2, pp. 365 - 371. DOI: 10.1016/j.ejor.2013.10.060.

KOMPA, K. - WITKOWSKA, D. (2016): Efficiency of Private Pension Funds in Poland. Aestimatio - The IEB International Journal of Finance, 12, pp. 48 - 64. DOI: 10.5605/IEB.12.3.

KONNO, H. - WAKI, H. - YUKKI, A. (2002): Portfolio Optimization under Lower Partial Risk Measures. Asia-Pacific Financial Markets, 9, No. 2, pp. 127 - 140. Available at: <https://doi.org/10.1023/A:1022238119491>.

KOTESOVCOVA, J. (2011): The Evaluation of Pension Funds in the World. Ostrava, In: Proceedings of 8th International Scientific Conference Financial Management of Firms and Financial Institutions, Czech Republic, pp. 175 - 184.

KRYGER, E. M. (2011): Fairness versus Efficiency of Pension Schemes. European Actuarial Journal, 1, pp. 85 - 100. Available at: <https://doi.org/10.1007/s13385-011-0012-6>.

LEJEUNE, M. A. (2011): A VaR Black-Litterman Model for the Construction of Absolute Return Fund-of-funds. Quantitative Finance, 11, No. 10, pp. 1489 - 1501. DOI: $10.1080 / 14697680903121018$.

LÓPEZ, F. - WALKER, E. (2021): Investment Performance, Regulation and Incentives: The Case of Chilean Pension Funds. Journal of Pension Economics and Finance, 20, No. 1, pp. 125 - 150. Available at: 〈https://doi.org/10.1017/S1474747219000350>.

MAKARSKI, K. - HAGEMEJER, J. - TYROWICZ, J. (2017): Analyzing the Efficiency of Pension Reform: The Role of the Welfare Effects of Fiscal Closures. Macroeconomic Dynamics, 21, No. 5, pp. 1205 - 1234. Available at: 〈https://doi.org/10.1017/S1365100515000383〉.

MARKOWITZ, H. (1952): Portfolio Selection. The Journal of Finance, 7, No. 1, pp. 77 - 91. Available at: <https://doi.org/10.2307/2975974>.

MARKOWITZ, H. (1959): Portfolio Selection: Efficient Diversification of Investments. Yale: Yale University Press. Available at: 〈http://www.jstor.org/stable/j.ctt1bh4c8h>.

MARTELLINI, L. - ZIEMANN, V. (2007): Extending Black-Litterman Analysis beyond the Mean-variance Framework. The Journal of Portfolio Management, 33, No. 4, pp. 33 - 44. Available at: <https://doi.org/10.3905/jpm.2007.690604>.

MARTI-BALLESTER, C. P. - PRIOR-JIMENEZ, D. (2010): Efficiency Analysis in the Spanish Pension Funds Industry: A Frontier Approach. In: MICOCCI, M., GREGORIOU, G. N. and MASALA, B. G. (eds): Pension Fund Risk Management: Financial and Actuarial Modeling. Boca Raton, USA: CRC Press-Taylor \& Francis Group, pp. 597 - 635.

MARTIN, K. J. - SANKARAN, H. (2019): Using the Black-Litterman Model: A View on Opinions. Journal of Investing, 28, No. 1, pp. $112-122$.

MATIC, B. - COBOVIC, M. V. (2017): Impact of Economic and Non-economic Factors on the Sustainability of the Pension System in Croatia. Ekonomski Vjesnik, 30, No. 1, pp. 51 - 65. Available at: <https://hrcak.srce.hr/183605>.

MAVlutovA, I. - TITOVA, S. - FOMINS, A. (2016): Pension System in Changing Economic Environment: Case of Latvia. Procedia Economics and Finance, 39, pp. 219 - 228.

DOI: 10.1016/S2212-5671(16)30316-1. 
MAVROTAS, G. (2009): Effective Implementation of the Epsilon-constraint Method in MultiObjective Mathematical Programming Problems. Applied Mathematics and Computation, 213, No. 2, pp. 455 - 465. DOI: 10.1016/j.amc.2009.03.037.

MICHAUD, R. O. (1989): The Markowitz Optimization Enigma: Is 'Optimized' Optimal? Financial Analysts Journal, 45, No. 1, pp. 31 - 42. DOI: 10.2469/faj.v45.n1.31.

MITKOVA, V. - MLYNAROVIC, V. - TUS, B. (2007): A Performance and Risk Analysis on the Slovak Private Pension Funds Market. Ekonomický časopis/Journal of Economics, 55, No. 3, pp. 232 - 249. Available at: <https://www.sav.sk/journals/uploads/0929113603\%2007\%20Mlynarovic.pdf>.

MLYNAROVIC, V. (2016): Legislative Changes Effects on Slovak Pension Funds Efficiency. In: Proceedings of the International Conference Quantitative Methods in Economics, Vratna, Slovakia, pp. 253 - 257. Available at: <http://www.fhi.sk/files/katedry/kove/ssov/proceedings/Zbornik2006.pdf〉.

OIKONOMOU, I. - PLATANAKIS, E. - SUTCLIFFE, C. (2018): Socially Responsible Investment Portfolios: Does the Optimalization Matter? British Accounting Review, 50, No. 4, pp. 379 - 401. DOI: 10.1016/j.bar.2017.10.003

PANG, T. - KARAN, C. (2018): A Closed-form Solution of the Black-Litterman Model with Conditional Value at Risk. Operations Research Letters, 46, No. 1, pp. $103-108$. DOI: 10.1016/j.orl.2017.11.014.

PLATANAKIS, E. - SUTCLIFFE, C. (2017): Asset-liability Modelling and Pension Schemes: The Application of Robust Optimization to USS. European Journal of Finance, 23, No. 4, pp. 324 - 352. DOI: 10.1080/1351847X.2015.1071714.

ROCKAFELLAR, R. T. - URYASEV, S. (2000): Optimization of Conditional Value-at-Risk. Journal of Risk, 2, No. 3, pp. 21 - 41. DOI: 10.21314/JOR.2000.038.

RODRIGUES, A. A. - LLEO, S. (2018): Combining Standard and Behavioral Portfolio Theories: A Practical and Intuitive Approach. Quantitative Finance, 18, No. 5, pp. 707 - 717. Available at: <https://doi.org/10.1080/14697688.2017.1401225>.

SERBANESCU, C. I. - PELE, D. T. (2011): A Quantitative Approach for the Financial Improvement of Private Pensions Systems. Romanian and Polish Perspective. Economic Computation and Economic Cybernetics Studies and Research, 45, No. 3, pp. 155 - 165. Available at: <http://www.ecocyb.ase.ro/eng.3\%20pdf/Daniel\%20Pele\%20_T_.pdf>.

STEUER, R. E. (1989): Multiple Criteria Optimization: Theory, Computation, and Application. Berkeley: Krieger. Available at: 〈https://doi.org/10.1002/oca.4660100109>.

SUN, L. (2017): Research on the Efficiency of Chinese Pension Insurance System Reform. Proceedings of the 2017 International Conference on Humanities Science, Management and Education Technology. Taiyuan, Peoples of China, pp. 512 - 517. Available at: <https://doi.org/10.2991/hsmet-17.2017.104>.

UYEN, G. J. (2016): The Effect of Private Pension Funds' Bidding on Fees and Competition. Revista Economia y Sociedad, 21, No. 50, pp. $1-17$. Available at: <https://doi.org/10.15359/eys.21-50.3>.

VYROST, T. - LYOCSA, S. (2014): Mean-variance Distance based Stock Market Networks in Portfolio Optimization. Proceedings of the 32nd International Conference on Mathematical Methods in Economics, Olomouc, Czech Republic, pp. 1090 - 1095. Available at: 〈http://mme2014.upol.cz/downloads/MME_2014_Proceedings.pdf >.

WITKOWSKA, D. - KOMPA, K. - MENTEL, G. (2019): The Effect of Government Decisions on the Efficiency of the Investment Funds Market in Poland. Journal of Business Economics and Management, 20, No. 3, pp. 573 - 594. Available at: 〈https://doi.org/10.3846/jbem.2019.9861〉.

ZHOU, G. (2009): Beyond Black-Litterman: Letting the Data Speak. Journal of Portfolio Management, 36, No. 1, pp. 36 - 45. DOI: 10.3905/JPM.2009.36.1.036. 